\title{
Effects of NMES and Horseback Riding Using a Robotic Device on the Trunk Muscle Activity and Gross Motor Function in Children with Spastic Diplegia
}

\author{
Shin-Jun Park', Pong-Sub Youn² \\ 'Department of Physical Therapy, GangDong University, Chungcheongbuk-do; ${ }^{2}$ Department of Physical Therapy, Bundang Jesaeng General Hospital, \\ Seongnam, Korea
}

Purpose: This study examined the effects of neuromuscular electrical stimulation (NMES) and horseback riding using a robotic device on the trunk muscle activity and gross motor function in children with spastic diplegia.

Methods: Children with spastic diplegia were divided into two groups: an experimental group (NMES and horseback riding using a robotic device $[n=10]$ ) and a control group (placebo NMES and horseback riding using a robotic device $[n=10])$. Each group received general physical therapy and occupational therapy. Each intervention involved the administration of NMES for 15 minutes and horseback riding using robotic device therapy for 15 minutes three times a week for 4 weeks. The evaluation included both the rectus abdominis muscles (RA), external oblique muscles (EO), thoracic paraspinal muscles (TP), and lumbar paraspinal muscles (LP) activity and GMFM.

Results: The RA, EO, TP, and LP muscle activity, GMFM C, D, and E were increased significantly in the experimental and control groups. A significant increase in both the TP muscle activity and GMFM D was observed in the experimental group compared to the control group. Conclusion: This study showed that horseback riding using a robotic device is an effective intervention for trunk muscle activity and GMFM in children with spastic diplegia. However, if NMES is added to the back muscles, it is possible to further increase the thoracic paraspinal muscle activity and standing ability.

Keywords: Neuromuscular electrical stimulation, Horseback riding using a robotic device, Trunk muscle activity, Gross motor function, Spastic diplegia

\section{서 론}

뇌성마비는 진행성 질환이 아니지만, 여러 가지 원인 인자에 의해 움 직임 및 자세 조절의 결핍으로 활동 제한이 나타나 시간이 지날수록 근골격계 변형이 나타난다. 뇌성마비 아동의 근력은 일반적으로 정 상 아동보다 감소하는데 몸통 근 활성도 감소는 보행 시 나타나고, ${ }^{2}$ 앉은 자세에서 과제를 수행할 때 몸통 근육보다 목 근육에 동원이 먼 저 일어나게 되어 과도한 길항근의 동시 활성(antagonistic co-activation) 때문에 자세 근육의 협응 장애가 나타난다. ${ }^{3}$ 지금까지 대부분의 근전도 연구들에서 뇌성마비 환자의 몸통 근 활성도는 중재 전에 근 활성도가 공통적으로 낮았지만 중재 후 근 활성도가 증가하는 특징 이 나타났다. ${ }^{4,5}$ 이처럼 뇌성마비 아동의 몸통 근 활성도는 저하가 나 타난다는 것이 일반적이다.
뇌성마비 아동의 몸통 근 활성도를 증가시킬 목적으로 시행된 연 구 중 로봇 승마운동이 있다. ${ }^{4}$ 로봇 승마운동은 실제 말을 타는 것과 같은 환경을 만들기 위해 앉은 자세에서 수행된다. 이 운동은 허리 골 반근육의 강화나, 짧아진 엉덩관절 모음근의 신장, 평형 반응 촉진, 선행적 자세 조절 및 척추의 곧은 자세를 개선하기 위한 운동으로 뇌 성마비 아동에게 적용 시 몸통 근육 두께와 대칭성을 회복시키고, ${ }^{4}$ 앉은자세 균형 및 자세 조절에 효과적인 방법이다. ${ }^{6}$

이전의 연구들은 승마운동이 뇌성마비 아동의 몸통 근 활성도를 증가시킨다고 하지만 승마운동 시 자세를 평가해 봤을 때 뇌성마비 아동은 약화된 몸통 안정성 근육과 안장 자체가 불안정할 수 있어서 앉은 자세에서 자세 조절이 어렵게 된다. 뇌성마비 아동의 경우 앉은 자세에서 척추 뒤 굽음증이 나타나게 되는데 주로 앉아서 생활하는 습관과 몸통 폄근의 약화 때문에 나타나며, ${ }^{8}$ 나이와 함께 증가하는
Received Jul 23, 2018 Revised Aug 16, 2018

Accepted Aug 31, 2018

Corresponding author Pong-Sub Youn

E-mail channom@naver.com
Copylight (C)2018 The Korea Society of Physical Therapy

This is an Open Access article distribute under the terms of the Creative Commons Attribution Non-commercial License (Http:// creativecommons.org/license/by-nc/4.o.) which permits unrestricted non-commercial use, distribution, and reproduction in any medium, provided the original work is properly cited. 
경향을 보인다.9 따라서 승마운동 시 등 굽이를 감소시킬만한 중재 방 법이 필요하다고 볼수 있다.

지금까지 뇌성마비 아동의 등 굽이 감소나 앉은 자세 몸통 조절을 개선하기 위한 연구는 보조기로 고정하거나 ${ }^{10}$ 테이핑으로 움직임을 보조하는 방법이 있다.1112 보조기 및 테이핑을 이용한 방법은 그 도 구를 제거하였을 때 효과가 연속되기 어렵고 환자에 맞게 제작해야 한다는 번거로움이 있다. 본 연구에서 실시하고자 하는 중재 방법은 전기 자극 방법으로 뇌성마비 아동에게 효과 및 사용에 대한 타당성 이 입증된 방법이다.1314 전기 자극은 단일 자극보다 다른 중재 방법과 결합하였을 때 그 효과가 더욱 뛰어나기 때문에 다른 중재와 복합적 으로 적용되고 있다.13,15 뇌성마비 아동의 복부와 등에 적용한 전기 자극 방법은 몸통 조절을 증가시키며 등 굽이 감소. ${ }^{15}$ 몸통 근 활성도 를 증진시킨다는 것이 확인되었다. ${ }^{5}$

이전 연구의 대부분은 전기 자극을 뇌성마비 아동의 운동치료나 5,15 보조 기계16와 결합한 연구였고 로봇 승마운동과 결합한 연구는 국내 외 미흡한 실정이다. 그뿐만 아니라 뇌성마비 아동에게 전기 자극을 통한 몸통 근 활성도를 증가시키기 위한 연구에서도 등 근육에 적용 한 연구는 전무한 실정이다. 비록 등 근육에 전기 자극과 안정화 운동 을 통해 신경계 손상 환자의 몸통 균형능력을 증진시킨 연구가 있지 만, ${ }^{17}$ 이 연구의 대상자는 뇌졸중 환자였고 평가 방법에 있어서도 모두 평가지만 사용했으므로 객관적인 근육 변화량은 확인하지 못하였다.

이에 본 연구의 목적은 뇌성마비 아동의 중재에 있어 등 근육에 전 기 자극과 승마운동을 결합하여 몸통 근 활성도와 대단위 운동 기능 에 미치는 영향을 파악하고, 승마운동을 단일 적용했을 때와 비교하 여 효과적인 중재 방법이 무엇인지를 제시하는 것이다.

\section{연구방법}

\section{1. 연구대상}

본 연구는 경기도에 위치한 J 종합병원에 입원 및 외래진료를 보는 뇌 성마비 아동 20 명을 대상으로 진행된 연구이다. 구체적인 대상자 선 정 기준은 이전에 승마운동을 경험해 보지 않은 아동, 승마운동 시 안장 위에 스스로 앉은 자세를 유지할 수 있거나 최소 한 사람의 도 움에 의해 앉을 수 있는 아동, 연구자의 지시에 따를 수 있거나 중등 도 이상의 정신지체가 없는 아동, 독립적으로 30 초간 선 자세를 유지 할 수 있는 아동, 등뼈 1 번과 등뼈 2번에 경사측정기(inclinometer)를 놓고 측정된 각도와 등빼 12 번과 허리뼈 1 번에 경사측정기를 놓고 측 정된 각도의 합을 등 굽이 각도로 하여 ${ }^{18} 26^{\circ}$ 이상 $55.8^{\circ}$ 이하인 아동 ${ }^{19}$ 을 대상으로 하였다. 만약 시각 및 청각 장애가 있거나 발작 가능성이 있는 아동, 연구일로부터 12 개월 이전에 신체기능과 관련된 수술이 나주사를 한 아동은 연구에서 제외하였다.
본 연구는 연구 참여자의 권익과 보호를 위해 용인대학교에서 기관 생명윤리 위원회(institutional review board) 승인을 받았고 연구자가 서면으로 작성한 “연구과제 피험자 동의서”를 각각의 대상자 보호자 에게 주어 연구자가 설명한 뒤 보호자에게 직접 서명을 받아 동의를 얻었다. 동의서에 서명한 연구 대상자는 신경근 전기 자극 후 로봇 승 마운동을 받는 연구군 10 명과 가짜 신경근 전기 자극 후 로봇 승마운 동을 받는 대조군 10 명으로 나누어 배치되었다. 아동이 거부한 경우, 통증 및 공포를 지속적으로 호소하는 경우, 퇴원한 경우, 개인 사정 및 보호자가 연구 중단을 원하는 대상자의 경우에는 연구를 중단하려 했으나 4 주간의 중재 기간 동안 탈락한 연구 대상자는 없었다.

\section{2. 실험방법}

1) 측정절차

본 연구에서는 중재 전 몸통 근 활성도와 대단위 운동기능을 측정하 였고, 모든 대상자는 4 주간의 중재 후 측정을 실시하였다.

\section{(1) 몸통근 활성도}

대상자의 몸통 근 활성도를 평가하기 위해 표면 근전도(TeleMyo 2400T G2 Noraxon, USA)를 사용하였다. 측정 근육으로는 양측 배곧 은근, 배 바깥빗근, 등 쪽 부척추근, 허리 쪽 부척추근으로 선정하였 다. 본 연구에 사용된 근전도는 유선 8 채널 표면 근전도로 표본 추출 률은 $1,000 \mathrm{~Hz}$ 이고, $10-500 \mathrm{~Hz}$ 범위에서 대역통과 필터(bandpass filter) 를 하였다. 수집된 모든 근전도 신호는 전파정류(full wave rectification)를 거쳐 제곱 평균제곱근(root mean square, RMS) 20 ms로 평활 처리하였다. ${ }^{20}$ 기준전극(reference electrode)은 위 앞 엉덩뼈가시(anterior superior iliac spine)로 하였고, 기록 전극은 근육의 근복(muscle belly)에 각각 부착하였다. 측정 전 전극의 부착부위를 마커로 표시해 두 고, 신뢰성을 높이기 위해 사진을 기록해 두었다. 부착부위 중 배 바 깥빗근은 배꼽으로부터 $15 \mathrm{~cm}$ 떨어진 지점과 갈비연골이 끝나는 지 점, 배곧은근은 배꼽으로부터 가 쪽으로 $2 \mathrm{~cm}$ 위쪽으로 $1 \mathrm{~cm}$ 떨어진 지점, 등 쪽 부척추근은 등뼈 중앙으로부터 가 쪽으로 $2 \mathrm{~cm}$ 떨어진 지 점, 허리 쪽 부척추근은 허리 뼈로부터 가 쪽으로 $1 \mathrm{~cm}$ 떨어진 지점으 로 하였다. 전극은 $\mathrm{Ag}-\mathrm{AgCl}$ 타입의 표면전극(외견: $24 \mathrm{~mm} \times 46 \mathrm{~mm}$, 전 극: $15 \mathrm{~mm} \times 15 \mathrm{~mm}$ )으로 가로가 짧고 세로가 긴 형태이다. 전극의 부 착 방향은 근섬유 주행 방향과 같은 방향으로 하였다. 본 연구에서는 뇌성마비 아동의 특성상 연구자의 지시를 정확히 알아들을 수 없는 대상자도 포함이 되므로 20초 동안 앉아있는 상태에서 안정 시 근전 도 신호값을 데이터 값(단위: $\mu \mathrm{V}$ )으로 하였다. ${ }^{5}$ 연구자는 피부 저항을 줄이기 위해 측정 부위를 의료용 알코올로 닦고 대상자들은 바로 앉 은 자세에서 전방에 집중할 수 있는 그림을 보도록 하였다. 
(2) 대단위운동 기능

대상자의 대단위 운동 기능을 평가하기 위해 한국판 대 동작 기능 평 가지(K-gross motor function measure, GMFM)를 이용하였다. 본 연구 에서 사용된 평가지는 뇌성마비 아동의 대운동 기능 변화를 평가하 기 위한 GMFM-88이었다. 평가지는 영역 A, B, C, D, E로 나누어져 있 으며 영역 $\mathrm{A}$ 는 눕기와 뒤집기(17 항목)로 점수는 51점이고, $\mathrm{B}$ 는 앉기 (20항목)로 점수의 합계는 60 점이다. 영역 $\mathrm{C}$ 는 네발 기기와 무릎 서기 (14 항목)로 점수의 합계는 42점, 영역 $\mathrm{D}$ 는 서기(13 항목)로 39점, 영역 $\mathrm{E}$ 는 걷기 및 달리기(24 항목)로 72 점이다. 각 항목 당 점수 산정은 0 점 부터 3점(likert type)으로 점수가 높을수록 동작을 완전히 수행하는 것을 의미한다.

각 영역별 \% 점수 계산은 영역 $\mathrm{A}$ 의 점수를 51 로 나눈 후 100 을 곱 하여 백분위를 구하였다. 같은 방법으로 영역 $\mathrm{B}, \mathrm{C}, \mathrm{D}, \mathrm{E}$ 의 점수를 각 각 $60,42,39,72$ 로 나눈 후 100 을 곱한 후 나머지 영역의 백분위를 구 하였다. 총점의 경우는 $\% \mathrm{~A}+\% \mathrm{~B}+\% \mathrm{C}+\% \mathrm{D}+\% \mathrm{E}$ 를 영역의 수인 5 로 나눈 후 \%로 나타내었다. GMFM의 A 영역, B 영역, C 영역, D 영역, E 영역, 총점의 급간 내 상관계수(intraclass correlation coefficients, ICCs)는 각 각 $0.88,0.94,0.91,0.76,0.98,0.94$ 로 높았다. ${ }^{21}$

\section{2) 중재방법}

본 연구에 참여한 모든 아동은 물리치료와 작업치료를 동일하게 적 용받는 대상자들이었다. 연구는 치료 일정이 끝난 후 신경근 전기 자 극과 로봇 승마운동을 실시하였다. 중재 기간은 4주간 일주일에 3 회 씩 신경근 전기 자극 15 분 후 로봇 승마운동 15 분을 규칙적으로 적용 받았다.

\section{(1) 신경근전기자극치료}

본 연구를 위해 전기 자극기(Microstim ${ }^{\circledR}$ Model GmbH, Stanberg, Germany)가 사용되었고 5.5-6.5 cm 크기의 표면전극 4개를 이용되었다. 전류를 통전하기 전 피부저항을 감소하고자 알코올로 통전할 부위 를 닦았다. 4 개의 전극 중 두 개의 전극은 등뼈 중앙을 기준으로 $2 \mathrm{~cm}$ 위쪽 부척 측근에 부착하였고 나머지 두 개의 전극은 $2 \mathrm{~m}$ 아래쪽 부 척추근에 부착하였다. 모든 전극은 척추뼈를 기준으로 $1 \mathrm{~cm}$ 가 쪽으 로 떨어진 지점에 간격을 두고 양쪽 부척추근(paravertebral muscles) 에 부착하였다. 전류 통전은 강도(intensity) 20-30 mA, 맥도 폭(pulse width) $250 \mu \mathrm{s}$, 주파수 $25 \mathrm{~Hz}, 10$ 초 자극 후 12초 휴식하는 통전-단락 시간으로 적용하였다. 전기 자극 수준은 수축이 일어날 때까지 적용 하였고, 환자가 수용할 수 있을 때 점진적으로 증가하였다. 전체 전류 통전 시간은 15 분으로 하였고, 얼굴을 찡그리거나 불쾌한 느낌, 공포 를 호소한다면 전류의 강도를 줄이고 지속적으로 호소한다면 중단 하려 하였지만 신경근 전기 자극 중 특이사항은 없었다. 가짜 신경근
전기자극치료는 동일한 기계에 전원을 켜고 강도, 맥도 폭, 주파수, 통 전-단락 시간을 설정하지 않은 채로 전기 자극 패드만 부착하였다.

\section{(2) 로봇 승마운동치료}

본 연구를 위해 로봇 승마운동 기계(FORTIS-201, Daewon Fortis, South Korea)가 사용되었다. 이 로봇 승마운동 기계에는 16 단계의 속 도와 실제 말의 움직임을 재현한(사인곡선의 상하 움직임) 16 개의 승 마 동작으로 구성되어 있다. 1 개의 승마 동작 당 5 초씩 자동으로 다 음 단계의 동작으로 이동되고 16 개의 승마 동작을 모두 체험하는 데 1 분 30 초가 소요된다. 본 연구에서는 $1-16$ 개의 승마 동작이 순차적으 로 이동되도록 자동 조절하였고 운동 강도는 속도로 조절하였다. 초 기 속도는 6 단계로 하였고, 5 분 후 8 단계, 5 분 후 10 단계로 하여 15 분 동안 중재를 실시하였다. 몸통 조절이 힘든 뇌성마비 아동에게는 안 전장치로만 사용되기 위해 하니스가 느슨하게 유지되어 착용되었고 모든 아동은 로봇 승마운동치료의 고삐형 손잡이를 잡도록 하였다. 또한, 낙상 및 안전사고를 방지하기 위해 한 명의 연구 보조자와 한 명 의 보호자가 옆에서 관찰하였다.

\section{3. 자료분석}

중재 후 몸통 근 활성도와 대단위 운동기능을 확인하기 위한 모든 데 이터 분석은 윈도용 SPSS 20.0 (SPSS Inc., Chicago, IL, USA) 프로그램 을 이용하였다. 연구 대상자의 일반적 특성 중 나이, 키, 몸무게, 사전 측정값은 독립 표본 t-검정을 이용하였고, 성별은 피어슨의 카이 제 곱을 이용하여 동질성을 확인하였다. 동질성 검정에 있어서 Levene 의 등 분산 검정이 $\mathrm{p}>0.05$ 라면 등 분산이 가정됨의 유의 확률을, $\mathrm{p}<0.05$ 라면 등 분산이 가정되지 않음의 유의 확률을 해석하였다. 연 구군과 대조군의 중재 전후 몸통 근 활성도와 대단위 운동기능 비교 는 연구 대상자의 중재 전후 비교는 대응 표본 t-검정을 이용하였다. 연구군과 대조군 사이에 사후 측정값, 사후 측정값에서 사전 측정값 의 차이 비교는 독립 표본 t-검정을 이용하였다. 본 연구의 통계적 유 의 확률 $\alpha=0.05$ 로 설정하였다.

\section{결 과}

\section{1. 연구 대상자의 일반적 특성}

본 연구에 참여한 뇌성마비 아동의 일반적 특성은 다음과 같다. 연구 군의 평균 나이는 $5.90 \pm 2.38$ 세이고, 평균 키는 $122.00 \pm 16.71 \mathrm{~cm}$, 평균 몸무게는 $25.50 \pm 8.23 \mathrm{~kg}$, 남아는 7 명, 여아는 3 명이었다. 대조군의 평 균 나이는 $5.50 \pm 1.96$ 세이고, 평균 키는 $115.00 \pm 19.05 \mathrm{~cm}$, 평균 몸무게 는 $19.80 \pm 5.22 \mathrm{~kg}$, 남아는 5 명, 여아는 5 명이었다. 독립 표본 $\mathrm{t}$-검정과 피어슨의 카이 제곱에서 두 군 간 유의 확률이 $\mathrm{p}>0.05$ 이므로 두 군 
간 일반적 특성에서 종질함을 확인할 수 있었다(Table 1)

Table 1. Subject characteristics

\begin{tabular}{lccc}
\hline Categories & $\begin{array}{c}\text { Experimental } \\
\text { group } \mathrm{n}=10\end{array}$ & $\begin{array}{c}\text { Control } \\
\text { group } \mathrm{n}=10\end{array}$ & $\mathrm{p}$ \\
\hline Age (year) & $5.90 \pm 2.38^{\mathrm{a}}$ & $5.50 \pm 1.96$ & $0.686^{\mathrm{b}}$ \\
Height $(\mathrm{cm})$ & $122.00 \pm 16.71$ & $115.00 \pm 19.05$ & 0.394 \\
Weight $(\mathrm{kg})$ & $25.50 \pm 8.23$ & $19.80 \pm 5.22$ & 0.080 \\
Gender (male/female) & $7 / 3$ & $5 / 5$ & $0.361^{\mathrm{c}}$ \\
\hline
\end{tabular}

${ }^{*} \mathrm{p}\left\langle 0.05 ;{ }^{a}\right.$ mean \pm standard deviation; ${ }^{b}$ independent smaples $t$-test; ${ }^{\text {Pearson }}$ chi square test.

Table 2. Comparison of before and after intervention

\begin{tabular}{|c|c|c|c|c|}
\hline Categories & & $\begin{array}{l}\text { Experimental } \\
\text { group }(n=10)\end{array}$ & $\begin{array}{c}\text { Control } \\
\text { group }(n=10)\end{array}$ & $\mathrm{p}$ \\
\hline \multirow[t]{4}{*}{ Left RA $(\mu \mathrm{V})$} & Pre & $9.58 \pm 5.80^{a}$ & $11.74 \pm 5.71$ & $0.548^{c}$ \\
\hline & Post & $11.96 \pm 5.20$ & $14.63 \pm 6.86$ & 0.350 \\
\hline & Change & $2.38 \pm 2.04$ & $2.88 \pm 2.97$ & 0.668 \\
\hline & $\mathrm{p}$ & $0.005^{* b}$ & $0.019^{*}$ & \\
\hline \multirow[t]{4}{*}{ Right RA $(\mu \mathrm{V})$} & Pre & $11.41 \pm 7.77$ & $9.50 \pm 5.18$ & 0.457 \\
\hline & Post & $13.83 \pm 9.38$ & $12.06 \pm 5.08$ & 0.621 \\
\hline & Change & $2.43 \pm 2.01$ & $2.53 \pm 3.03$ & 0.914 \\
\hline & $\mathrm{p}$ & $0.004^{*}$ & $0.035^{*}$ & \\
\hline \multirow[t]{4}{*}{ Left EO $(\mu \mathrm{V})$} & Pre & $11.30 \pm 5.20$ & $9.65 \pm 6.36$ & 0.535 \\
\hline & Post & $14.06 \pm 6.37$ & $12.33 \pm 7.30$ & 0.579 \\
\hline & Change & $2.77 \pm 2.85$ & $2.68 \pm 1.56$ & 0.933 \\
\hline & $\mathrm{p}$ & $0.013^{*}$ & $0.001^{*}$ & \\
\hline \multirow[t]{4}{*}{ Right EO $(\mu \mathrm{V})$} & Pre & $12.29 \pm 4.92$ & $10.47 \pm 7.41$ & 0.526 \\
\hline & Post & $15.54 \pm 6.60$ & $11.97 \pm 7.58$ & 0.276 \\
\hline & Change & $3.25 \pm 3.25$ & $1.50 \pm 1.45$ & 0.137 \\
\hline & $\mathrm{p}$ & $0.011^{*}$ & $0.009^{*}$ & \\
\hline \multirow[t]{4}{*}{ Left TP $(\mu \bigvee)$} & Pre & $15.57 \pm 5.58$ & $15.82 \pm 2.30$ & 0.912 \\
\hline & Post & $18.97 \pm 4.64$ & $17.35 \pm 1.53$ & 0.331 \\
\hline & Change & $3.41 \pm 1.20$ & $1.53 \pm 1.83$ & $0.049^{*}$ \\
\hline & $\mathrm{p}$ & $0.001^{*}$ & $0.037^{\star}$ & \\
\hline \multirow[t]{4}{*}{ Right TP $(\mu \mathrm{V})$} & Pre & $15.59 \pm 5.31$ & $16.42 \pm 1.13$ & 0.508 \\
\hline & Post & $19.65 \pm 5.38$ & $17.56 \pm 1.68$ & 0.280 \\
\hline & Change & $4.06 \pm 1.88$ & $1.14 \pm 1.37$ & $0.001^{*}$ \\
\hline & $\mathrm{p}$ & $0.001^{*}$ & $0.028^{*}$ & \\
\hline \multirow[t]{4}{*}{ Left LP $(\mu \mathrm{V})$} & Pre & $25.89 \pm 3.31$ & $24.26 \pm 6.02$ & 0.789 \\
\hline & Post & $28.36 \pm 2.99$ & $25.88 \pm 5.66$ & 0.243 \\
\hline & Change & $2.46 \pm 1.76$ & $1.62 \pm 1.37$ & 0.267 \\
\hline & $\mathrm{p}$ & $0.002^{*}$ & $0.008^{*}$ & \\
\hline \multirow[t]{4}{*}{ Right LP $(\mu \mathrm{V})$} & Pre & $25.90 \pm 5.08$ & $27.45 \pm 7.86$ & 0.448 \\
\hline & Post & $28.44 \pm 4.59$ & $28.71 \pm 7.24$ & 0.925 \\
\hline & Change & $2.54 \pm 2.62$ & $1.26 \pm 1.44$ & 0.212 \\
\hline & $\mathrm{p}$ & $0.013^{*}$ & $0.031^{*}$ & \\
\hline
\end{tabular}

RA: rectus abdominis muscles, EO: external oblique muscles, TP: thoracic paraspinal muscles, LP: lumbar paraspinal muscles.

${ }^{*} \mathrm{p}<0.05$, amean \pm standard deviation, bpaired t-test, cindependent smaples t-test.

\section{2. 연구군과 대조군의 몸통근 활성도 변화}

본 연구에 참여한 뇌성마비 아동의 앉은 자세 몸통 근 활성도 변화 는 다음과 같다.

중재 후 연구군은 왼쪽 배곧은근, 오른쪽 배곧은근, 왼쪽 배 바깥 빗근, 오른쪽 배 바깥빗근, 왼쪽의 등 쪽 부척추근, 오른쪽의 등 쪽부 척추근, 왼쪽의 허리 쪽 부척추근, 오른쪽의 허리 쪽 부척추근 활성 도가 모두 유의하게 증가하였다.

대조군에서도 왼쪽 배곧은근, 오른쪽 배곧은근, 왼쪽 배 바깥빗근, 오른쪽 배 바깥빗근, 왼쪽의 등 쪽 부척추근, 오른쪽의 등 쪽 부척추 근, 왼쪽의 허리 쪽 부척추근, 오른쪽의 허리 쪽 부척추근 활성도도 가 모두 유의하게 증가하였다.

연구군과 대조군 사이에 사후 측정값에서 사전 측정값의 차이 비 교에서 연구군이 대조군보다 왼쪽과 오른쪽 등 쪽 부척추근 활성도 가 유의하게 증가하였음을 알 수 있었다. 또한, 연구군과 대조군 사이 에 사전 측정값의 차이 비교에서 유의한 차이가 없었으므로 초기 몸 통 근 활성도에 동질함을 알 수 있었다(Table 2).

Table 3. Comparison of before and after intervention

\begin{tabular}{|c|c|c|c|c|}
\hline Categories & & $\begin{array}{l}\text { Experimental } \\
\text { group }(n=10)\end{array}$ & $\begin{array}{c}\text { Control } \\
\text { group }(n=10)\end{array}$ & $p$ \\
\hline GMFM & Pre & $100.00 \pm 0.00^{\mathrm{a}}$ & $99.02 \pm 3.10$ & $0.331^{c}$ \\
\hline \multirow[t]{3}{*}{ A (\%) } & Post & $100.00 \pm 0.00$ & $100.00 \pm 0.00$ & 1.000 \\
\hline & Change & $0.00 \pm 0.00$ & $0.98 \pm 3.01$ & 0.343 \\
\hline & $\mathrm{p}$ & $1^{\mathrm{b}}$ & 0.343 & \\
\hline GMFM & Pre & $96.03 \pm 7.17$ & $84.37 \pm 26.87$ & 0.213 \\
\hline \multirow[t]{3}{*}{ B (\%) } & Post & $98.67 \pm 3.67$ & $88.33 \pm 23.75$ & 0.205 \\
\hline & Change & $2.64 \pm 4.02$ & $3.96 \pm 5.03$ & 0.523 \\
\hline & $\mathrm{p}$ & $0.068^{*}$ & $0.034^{*}$ & \\
\hline GMFM & Pre & $85.03 \pm 9.60$ & $61.99 \pm 33.09$ & 0.059 \\
\hline \multirow[t]{3}{*}{ C (\%) } & Post & $91.21 \pm 8.04$ & $70.00 \pm 33.11$ & 0.077 \\
\hline & Change & $6.18 \pm 5.67$ & $8.01 \pm 5.93$ & 0.489 \\
\hline & $\mathrm{p}$ & $0.007^{\star}$ & $0.002^{*}$ & \\
\hline GMFM & Pre & $50.22 \pm 17.21$ & $32.49 \pm 31.48$ & 0.141 \\
\hline \multirow[t]{3}{*}{$\mathrm{D}(\%)$} & Post & $67.97 \pm 15.35$ & $41.55 \pm 34.84$ & $0.048^{*}$ \\
\hline & Change & $17.75 \pm 9.22$ & $9.06 \pm 8.56$ & $0.042^{*}$ \\
\hline & $\mathrm{p}$ & $0.001^{*}$ & $0.009^{*}$ & \\
\hline GMFM & Pre & $23.93 \pm 12.92$ & $16.90 \pm 20.01$ & 0.365 \\
\hline \multirow[t]{3}{*}{$E(\%)$} & Post & $34.71 \pm 22.66$ & $23.60 \pm 22.81$ & 0.289 \\
\hline & Change & $10.78 \pm 12.11$ & $6.70 \pm 3.83$ & 0.324 \\
\hline & $\mathrm{p}$ & $0.020^{*}$ & $0.001^{*}$ & \\
\hline GMFM & Pre & $71.04 \pm 8.22$ & $58.95 \pm 20.61$ & 0.111 \\
\hline \multirow[t]{3}{*}{ total (\%) } & Post & $78.51 \pm 8.84$ & $64.70 \pm 20.90$ & 0.070 \\
\hline & Change & $7.47 \pm 3.14$ & $5.74 \pm 2.69$ & 0.204 \\
\hline & $\mathrm{p}$ & $0.001^{*}$ & $0.001^{*}$ & \\
\hline
\end{tabular}

GMFM: gross motor function measure.

${ }^{*} \mathrm{p}\left\langle 0.05 ;{ }^{a}\right.$ mean \pm standard deviation; ${ }^{b}$ paired $t$-test; ; independent smaples t-test. 


\section{3. 연구군과 대조군의 대단위운동 기능변화}

본 연구에 참여한 뇌성마비 아동의 대단위운동 기능 변화는 다음과 같다.

중재 후 연구군은 GMFM 영역 A와 B에서 유의한 차이가 없었으 나, GMFM 영역 C, D, E, 총점은 유의하게 증가하였다.

대조군은 GMFM 영역 A에서 유의한 차이가 없었고, GMFM 영역 $\mathrm{B}, \mathrm{C}, \mathrm{D}$, 총점은 유의하게 증가하였다.

연구군과 대조군 사이에 사후 측정값에서 사전 측정값의 차이 비 교에서 연구군이 대조군보다 GMFM 영역 D가 유의하게 증가하였고, 사후 측정값 비교에서도 연구군이 대조군보다 GMFM 영역 D가 유 의하게 증가하였음을 알 수 있었다. 또한, 연구군과 대조군 사이에 사 전 측정값의 차이 비교에서 유의한 차이가 없었으므로 초기 대단위 운동 기능에 동질함을 알 수 있었다(Table 3).

\section{고 찰}

뇌성마비 아동의 등 굽이에 관한 문헌조사에 따르면, 뇌성마비 아동 은 앉은 자세에서 뒤 굽음 증가가 나타나고 청소년기로 갈수록 증가 하게 되는데 이것은 머리를 올바르게 세워 놓을 수 없게 되고 통증 및 피로감을 유발하게 된다. 등 굽이가 심해질수록 뇌성마비 아동은 호흡 기능에도 영향을 미칠 수 있기 때문에 ${ }^{22}$ 등 굽이를 감소시킬만 한 중재 방법 개발이 필요하다고 판단하여 본 연구에서는 분 척추 근 육에 전기 자극을 적용하였다. 또한, 로봇 승마운동은 흥미가 있어야 하는 뇌성마비 아동에게 재미있고, 쉽게 접근할 수 있는 이점이 있으 므로 본 연구에서는 전기 자극 후 로봇 승마운동과 로봇 승마운동 단일 적용을 4 주간 실시하여 다음과 같은 결과를 얻었다.

로봇 승마운동 후 배곧은근, 배 바깥빗근, 등 쪽 부척추근, 허리 쪽 부척추근 활성도에 유의한 증가가 있었고, GMFM 앉기, 네발 기기와 무릎 서기, 서기, 걷기 및 달리기의 영역과 총 점수에 유의한 증가가 있 었다.

뇌성마비 아동에게 승마운동은 팔꿉 및 무릎관절 MAS의 감소와 함께 넙다리뒤근과 위팔두갈래근 활성도가 증가와 23 복부근, 척추세 움근 활성도 증가, ${ }^{4} \mathrm{GMFM}$ 모든 영역의 개선이 가능하다. ${ }^{24}$ 선행연구 에서는 승마 로봇이 싸인 곡선 형태를 그리며 움직이는 동안 몸통의 근육 참여가 몸통 조절 능력을 향상시켰기 때문인 것이라 하였 다. 4,23,24 본 연구에서도 이를 확인할 수 있었고 선행연구 결과와 같았 다. 하지만 중재 효과를 확인한 선행연구에서는 12 주, ${ }^{24} 5$ 주, ${ }^{4} 6$ 주 및 8 주로 ${ }^{23} 5$ 주 이상의 기간이 걸렸고 본 연구에서는 4 주 후에 근 활성도 및 GMFM 눕기와 뒤집기 영역을 제외한 모든 \% 점수에도 유의한 증 가하였으므로 적용 기간에 따른 임상적 의의가 있다.

본 연구에서 전기 자극과 로봇 승마운동 후 배곧은근, 배 바깥빗
근, 등 쪽 부척추근, 허리 쪽 부척추근 활성도, GMFM의 무릎 서기, 서 기, 걷기 및 달리기의 영역과 총 점수에 유의한 증가가 있었고, 단일 로봇 승마운동 보다 등 쪽 부척추근과 GMFM 서기 D 영역 점수에 유 의한 증가가 있었다. 로봇 승마운동과 트레드밀 운동에 대한 근전도 분석 연구에서 로봇 승마운동과 트레드밀 운동은 모두 비슷한 양상 으로 근 활성도가 증가하였으나 배가로근은 로봇 승마운동이 더욱 증가하였고 척추세움근은 트레드밀 운동에서 유의하게 증가하였 다. ${ }^{25}$ 이처럼 승마운동은 척추세움근보다 복부 근육에 더 큰 활성도 를 보이는데 선행연구자는 말고삐를 잡거나 당기는 운동을 했기 때 문이라고 하였다. ${ }^{25}$ 신경학적 손상이 있는 환자에서 승마 안장의 좌 석은 비대칭적인 좌안을 유발할 수 있다. ${ }^{6}$ 더하여 뇌성마비 아동의 등 근육 약화가 뒤 굽음증을 야기할 수 있기 때문에 ${ }^{8}$ 본 연구에서는 등 쪽 분 척추 근육에 전기 자극을 했고 그에 따른 결과로 등 쪽 부척 추근 활성도에 더 큰 증가를 확인하였다.

뇌성마비 아동의 등과 배에 전기자극을 실시한 연구에서 목빗근, 배곧은근, 목폄근, 등폄근 활성도에 유의한 증가가 있었다. 선행연구 자는 전기자극이 몸통 근육을 자극하여 근력을 증가시켰을 수 도 있 지만 뇌성마비 아동에서 과도한 동시활성 때문에 나타난 결과도 배 제할 수 없다 하였다. 다만 전기자극 후 GMFM의 무릎서기, 서기, 걷 기 및 달리기의 영역과 총 점수에 유의한 증가가 있었고, ${ }^{5} \mathrm{GMFM}$ 점 수가 높을수록 더 나은 운동기능을 보이기 때문에 몸통 근활성도 증 가를 긍정적인 쪽으로 생각할 수 있다.

배와 등에 적용한 전기자극은 등굽이 각도 감소와 함께 GMFM 앉 기 영역 점수가 증가를 보였고, ${ }^{27}$ 다른 선행연구에서도 몸통에 전기 자극 후 GMFM의 앉기 영역만 전기자극을 하지 않았을 때 보다 유의 한 증가를 보였다. ${ }^{5}$ 하지만 본 연구에서는 중재 후 앉기 영역에서는 유 의한 차이가 없었던 반면, 서기 영역에서 전기자극을 적용한 연구군 이 대조군보다 유의한 증가가 있었다. 이러한 차이는 대상자의 신체 기능과 로봇 승마운동에 비롯된 결과에 따른 차이로 사료된다.

본 연구에 참여한 대상자의 앉기 점수는 연구군의 경우 중재 전 $96.03 \pm 7.17$ 점으로 이미 앉기 기능에 큰 문제가 없는 대상자들이었다. 본 연구의 로봇 승마운동을 적용하기 위해서는 앉는 운동기능이 완 전히 수행되어야 중재를 시행할 수 있었으므로 앉기 영역에 관한 천 장 효과 때문에 나타난 결과였던 것으로 사료된다. 로봇 승마운동은 전신의 근 활성도가 증가가 가능하며, 특히 배가로근, 배 바깥빗근, 긴 모음과 같이 방향 전환이나 몸통을 돌리는 근육에 관해서는 트레드 밀 운동보다 오히려 승마운동이 더 큰 활성도를 보인다. ${ }^{25} \mathrm{GMFM}$ 의 서기 D 영역 중 60 번에서 64 번까지 항목은 모두 앉아 일어서는 동작 으로 구성됐다. 따라서 대조군보다 등 쪽 부척근 활성도 증가를 보였 던 연구군은 전기 자극이 승마 운동 시 척추의 곧은 자세를 유지하 는 데 도움이 되었고 그 결과로 인체의 고른 근 수축의 참여를 통해 
서기 영역 평가 중 앉아 일어서기와 같이 허리를 사용하는 평가에서 보다 개선을 보여 나타났던 결과로 사료된다. 또한, 본 연구에 선정된 대상자는 등 굽이 각도가 $26^{\circ}$ 이상 $55.8^{\circ}$ 이하인 아동이었다. 선행연구 에서 등 굽이가 증가하는 웅크린 자세일수록 척추세움근 중 가장 긴 근(longissimus muscle)에 활성도가 감소되고 허리를 곧게 세울수록 근 활성도가 더 크게 증가한다고 하였다. ${ }^{28}$ 이러한 결과는 등 쪽 부척 추근에서만 더욱 증가한 본 연구 결과를 지지한다.

이 연구에서는 척추의 정렬을 객관적으로 확인할 수 없었고, 등 굽 이가 있는 대상자들만 선정하였기 때문에 모든 뇌성마비 아동에게 일반화시킬 수 없다. 하지만 지금까지 선행연구와 차이가 있었던 배 쪽의 전기 자극이 없는 상태에서 등 쪽의 전기 자극 집중이 전기 자 극을 하지 않았을 때보다 등 쪽 척추세움근 활성도에 더 큰 영향을 미치고 서기 능력에서도 더 큰 향상을 본 연구에서 확인하였다. 향후 연구에서는 척추의 정렬과 함께 여러 가지 배치법을 가지고 가장 효 과적인 부착부위를 확인하는 것이 필요하겠다.

\section{참고문헌}

1. Gajdosik CG, Cicirello N. Secondary conditions of the musculoskeletal system in adolescents and adults with cerebral palsy. Phys Occup Ther Pediatr. 2001;21(4):49-68.

2. Burtner PA, Qualls C, Woollacott MH. Muscle activation characteristics of stance balance control in children with spastic cerebral palsy. Gait Posture. 1998;8(3):163-74.

3. van der Heide JC, Hadders-Algra M. Postural muscle dyscoordination in children with cerebral palsy. Neural Plast. 2005;12(2-3):197-203.

4. Lee DR, Lee NG, Cha HJ et al. The effect of robo-horseback riding therapy on spinal alignment and associated muscle size in MRI for a child with neuromuscular scoliosis: an experimenter-blind study. NeuroRehabilitation. 2011;29(1):23-7.

5. Jung JW, Song B. The effects of neuromuscular electrical stimulation over trunk muscles on gross motor function and trunk muscle activity in children with cerebral. Journal of Rehabilitation Research. 2012;16:293-314.

6. Cha YJ, Stanley M, Shurtleff T et al. Long-term effects of robotic hippotherapy on dynamic postural stability in cerebral palsy. Computer Assisted Surgery. 2016;21(suppl):111-5.

7. Medeiros M. Adaptation of the seated postural control measure for children/youth with neuromotor disorders during therapeutic horseback riding/hippotherapy: a pilot project for development and reliability. Manitoba University. Dissertation of Master's Degree. 2017

8. Umnov VV. Kyphosis in patients with cerebral palsy: Causes of its development and correctional possibilities (literature review). Pediatric Traumatology, Orthopaedics and Reconstructive Surgery. 2015;3(3):48-51.

9. Lee SY, Chung CY, Lee KM et al. Annual changes in radiographic indices of the spine in cerebral palsy patients. Eur Spine J. 2016;25(3):679-86.

10. Vekerdy Z. Management of seating posture of children with cerebral palsy by using thoracic-lumbar-sacral orthosis with non-rigid SIDO frame. Disabil Rehabil. 2007;29(18):1434-41.

11 Şimşek TT, Türkücüoğlu B, Çokal N et al. The effects of Kinesio ${ }^{\circledR}$ taping on sitting posture, functional independence and gross motor function in children with cerebral palsy. Disabil Rehabil. 2011;33(21-22):2058-63.

12. Footer CB. The effects of therapeutic taping on gross motor function in children with cerebral palsy. Pediatr Phys Ther. 2006;18(4):245-52.

13. Wright PA, Durham S, Ewins DJ et al. Neuromuscular electrical stimulation for children with cerebral palsy: A review. Arch Dis Child. 2012; 97(4): 364-71.

14. Chiu HC, Ada L. Effect of functional electrical stimulation on activity in children with cerebral palsy: A systematic review. Pediatr Phys Ther. 2014; 26(3):283-8.

15. Karabay I, Dogan A, Arslan MD et al. Effects of functional electrical stimulation on trunk control in children with diplegic cerebral palsy. Disabil Rehabil. 2012;34(11):965-70.

16. Scheker LR, Chesher SP, Ramirez S. Neuromuscular electrical stimulation and dynamic bracing as a treatment for upper-extremity spasticity in children with cerebral palsy. J Hand Surg Br. 1999;24(2):226-32.

17. Ko EJ, Chun MH, Kim DY et al. The additive effects of core muscle strengthening and trunk NMES on trunk balance in stroke patients. Ann Rehabil Med. 2016;40(1):142-51.

18. Lewis JS, Valentine RE. Clinical measurement of the thoracic kyphosis. A study of the intra-rater reliability in subjects with and without shoulder pain. BMC Musculoskelet Disord. 2010;11(1):39.

19. Tsirikos AI, Chang WN, Dabney KW et al. Life expectancy in pediatric patients with cerebral palsy and neuromuscular scoliosis who underwent spinal fusion. Dev Med Child Neurol. 2003;45(10):677-82.

20. Jung KS, Kim YS, In TS. Effects of the support surface condition on muscle activity of trunk muscles during balance exercises in patients with stroke. J Kor Phys Ther. 2015;27(4):196-200.

21. Yi CH, Hwang SG, Choi HS. Inter-rater reliability of the gross motor function. Phys Ther Korea. 1995;2(1):1-13.

22. Shin HK, Byeon EJ, Kim SH. Effects of seat surface inclination on respiration and speech production in children with spastic cerebral palsy. J Physiol Anthropol. 2015;34(1):17.

23. Lee IS, Kim JS, Kim SY. The effect of hippotherapy on spasticity and muscular activity in children with cerebral palsy. J Korean Soc Occup Ther. 2011;19(1):117-24.

24. Kang KY, Song BH. Effects of horseback riding simulation machine training on gross motor function for the children with cerebral palsy. J of KoCon. a. 2010;10(5):277-84.

25. Beack JH, Sung BJ, Lee BW. The analysis of electromyogram in horse riding simulator. Journal of Sport and Leisure Studies. 2005;23:341-52.

26. Park SY, Lee IH, Jeon CB et al. Comparison of the sitting pressure of stroke patients according to seat shapes. J Ergon Soc Korea. 2010;10:15-9.

27. Park ES, Park CI, Lee HJ. The effect of electrical stimulation on the trunk control in young children with spastic diplegic cerebral palsy. J Korean Med Sci. 2001;16(3):347-50.

28. Claus AP, Hides JA, Moseley GL et al. Different ways to balance the spine: subtle changes in sagittal spinal curves affect regional muscle activity. Spine. 2009;34(6):E208-14. 